Ezekiel, Ezekiel, you saw the wheel: in the middle of the air. Will you help, Ezekiel, to resurrect our manly spirits to see the wheel of thought and imagination? Ezekiel Mphahlele (it sounds poetic: Mphahlele Ezekiel) teach us to write. Open our mouths. Else we choke with lumps of thought. Else we go migrating in search of inspiration to Mbari. Else we cut Ulli Beier into two and leave Nigeria with the legs.

We want more. But we do not even have any yet. Could we find an alchemist? An alchemist to change Moore, Gerald Moore, into a tribesman to give us another Mbari? Moore, will you teach us only to comment?

No longer can Taban or anyone else call East Africa barren in literature. The driving force behind the birth of its literature has been identified by Ngugi. He says, "Now there are only two tribes left in Africa: the 'haves' and the 'have-nots.' What goes for tribalism in Africa is really a form of civil war among the 'haves,' struggling for crumbs from the masters' tables. The masters sit in New York, London, Brussels, Paris, Bonn and Copenhagen; they are the owners of the oil companies, the mines, the banks, the breweries, the insurance institutions-all the moving levers of the economy. It is this situation that has given us A Man of the People, Song of Lawino, Voices in the Dark. It is this that is behind the critical self-appraisal and the despair in much of the current African literature." The struggle continues in life as in East African literature.

JOUNG HYUN-JONG / KOREA

\title{
Poetry as a Possibility of Life
}

Contemporary poetry has introduced freedom in the very body of the language. As a result, poetry appears as a phenomenon of freedom.

-Gaston Bachelard

Many Korean poets and critics agree that the traditional and remarkable quality of Korean poetry is what we call in Korean han. The meaning of the word han is so complex that it can hardly be translated into one 
English term, but it has such meanings as grudge or resentment, regret, discontent, resignation, frustration, and lamentation. Nevertheless we Koreans understand the meaning of the word almost intuitively in its historical, cultural context. This han also dominated modern Korean poetry since the 1920 's, when Korea was under the Japanese colonial rule, and it has penetrated not only into some works of the poets of the forties but also those of younger poets. And younger poets and critics agree that han in Korean poetry is something that must be transcended. So I am going to speak about what han is, why it must be transcended, and how younger Korean poets are trying to go beyond it.

There is an expression in Korean which can be roughly translated, "to bear han in one's heart." The cause of "bearing han" may lie in the personality or the growing process, but it is not easy to locate the cause thus because a person is organically connected with the society to which he belongs.

Clearly, I think, han is a product of a closed society. It occurs when one, as a free and independent person, is limited in his possibility of life by external powers, and occurs in the state which prohibits any effort to better the conditions of human life.

Han has no relation to man's struggle for freedom, independence and happiness. So it can be said that it is a betrayal of life. Han may stem from the occupation by alien powers, or an unjust political system or ideology of a country. It seems only human and natural that one bears rancor, hate or grief in the condition of oppression in a closed society. But one is dominated by han, and consequently the possibility of life or creative power is thwarted, and he will fall into a mean sentimentalism or all forms of human perversion. In such a society as is characterized by the relation of the ruling and the ruled, one may form the habit of submitting to destructive powers which restrict and threaten us, so that human liberation is not possible. Instead of bearing han, we have to live in creative tension in which we must see and contemplate our experience with clear consciousness.

(Bachelard says, when he talks about poetic reverie, that "in poetic reverie the soul keeps watch, with no tension, calmed and active." This word shows another nature of tension, which we can verify by means of the metaphysics of tension. As Wallace Stevens discerns the two phases of imagination, tension also has two phases: tension as metaphysics and tension as a power of the mind over external objects.)

Objects in the modern world oppress, frustrate and irritate us. We may become their slaves and lose our dignity as men. Yet we cannot do without them. We must learn to maintain creative tension vis-a-vis objects.

Han is given full rein in one poem and it is controlled in the other. There may be many different causes: differences in personality, intellectual abil- 
ity and the quality of emotions, linguistic sensibility or history, and the poetic talent resulting from these differences. Yet I think-in spite of $m y$ oversimplification-it depends on whether a poet has a way of maintaining creative tension with the objects which provoke and oppress him or not.

Korean poetry since the 1930's, though there are such distinguished poets as Han Yong-un (1879-1944), Joung Ji-yong (1903- ? ), and So Chong-ju (1915- ), has been mainly characterized by han or the distorted state of han. For example, I would like to cite a famous and widely-read poem in Korea-“Azaleas," by Kim So-wol (1902-1934):

When you go away

Sick of me

I will gently let you go in silence.

I will gather

An armful of azaleas

At Yaksan, Yonbyon,

And scatter them on your path.

Tred gently

Step by step

Upon the flowers as you go.

When you go away

Sick of me

No tears I will shed

Even if I perish.

The central emotions of this poem, I think, are regressive resignations, feminine submission and tears imprisoned in the broken heart rather than gentleness or kindness. It is apparent that the grief, resignation or resentment is one of our natural emotions, and it is not impossible to have an emotional leaning that may be called feminine, but it is important to ask what it is for. Grief for the sake of grief, resignation for the sake of resignation, etc., is but an obstacle to our realization of life. Needless to say, that is a sentimentality-a failure of feeling.

$\mathrm{Han}$ is a relative conception; it acquires meaning only in relation to some precedent causes. So it is important to know how to "receive" poetic objects and make a song, and then this means nothing but that the poet must know how to "receive" himself and express himself. Words are, I believe, the very field of our life, and words, or the space of imagination, have the energy to open up the new being. 
No objects can oppress, devastate and atrophy the poet's mind or feeling. He would live in the freedom of mind-as continuously as possible. If he does not liberate himself, nobody can liberate him. And only the free mind can make others free, liberate them into truth, thereby increase the joys or happiness of life.

In contrast to Kim So-wol, Han Young-un, a devout Buddhist monk, activist, and poet, said, "Parting is a creation of beauty":

Parting is a creation of beauty,

There is no beauty of parting in the ethereal gold of morning, in the seamless dark silk of night, eternal life without death and the blue flowers of heaven that withers not.

My love, without parting I cannot die and be born again in tears. Oh parting!

Beauty is a creation of parting.

This poet wasn't overwhelmed by han at or after parting, and the paradox of the poem reveals his positive understanding about his painful experience. Perhaps we may call it "ultimate yea."

The poetry of young Korean poets shows two tendencies as a whole. One tendency insists on maintaining a critical attitude toward the contradictions of political and social reality, and the other is attached to the inner space of man, which may be called a surrealistic space. The former is concerned with a public world in its outer-directedness, the latter is concerned with the world of the individual. If the political poet's moral passion expresses itself, however, as the raw stuff of hate or grudge, it gives us unpleasantness instead of moving us. The inner-directed poem is liable to become an empty somniloquy if it hasn't any inner necessity. In either case the uncontrolled expression of han diminishes the reality and effect of poetry. Without the spiritual discipline of multiple thinking and distanced emotion, it is doubtful that good poetry would come to us.

In the following poem, for example, hate or resentment is controlled by intellect:

Sometimes a king is but a shadow of his subjects.

When you, my lords, rise to raise me

as I kneel below the throne,

and lead me through the back garden

blooming with peonies,

I will not see

the morning or evening papers

or the telescopes

but I will roam among the lonely flowers. 
There comes a time a king should know when to depart. Like the chief of a tribe and his sons who burn themselves in a lean year (they shout, but with no sound, no cough, no illness, no thatched houses), he should know when to depart.

No unhappiness, no life.

Surely there will be a time when someone will remember them, the wishes suspended over our twists and turns? In the dark sky burning clouds fall here and there, and darkness comes to every corner.

Kneeling, I want to fall, fall like a lump of clay during the thaw and float along the east sea, the south sea, the west sea, and be caught somewhere, my body changed into their ecstasy. The wind blows.

\section{Hwang Dong-ku, "Notes of a King"}

In this poem we can find "objective correlatives" or indirect substitutions that represent the poet's emotions and consciousness.

The sensibility of the poet feels, like an antenna, the pain of his age most keenly. If Korean poets have pained hearts, it may be because they live in an age of distress.

The place of poetry is at the point of contact between man's inside and outside. The poet speaks on the threshold of being. Isn't it merely a private han if, in poetry, individual experience is not sublimated into universal truth? The poet must represent the whole of life and must live in us as a total man; we want the convincing identity of a poet.

Therefore the poet must move to an impersonal strength, then work will become a bright spiritual heritage for human society. And the impersonal strength will come into being when the poet searches for a persona, a public personality: the mask presented to satisfy the demands of the situation or the environment. In other words, persona means the politics of love.

Poetry is an art of possibility, that is, the world of imagination. And that imagination is the very phenomenon of freedom. The poet, as a total man, as a man of imagination, or a dreamer, embraces our life to his innocent, vital soul.

Translated by Kim Woo Chang 